\title{
Temporal Artery Biopsy for Diagnosing Giant Cell Arteritis: A Ten-year Review
}

\author{
Kaveh Abri Aghdam, MD, PhD; Mostafa Soltan Sanjari, MD; Navid Manafi, MD; Shabnam Khorramdel, MD \\ Sayyed Amirpooya Alemzadeh, MD; Roshanak Ali Akbar Navahi, MD
}

Eye Research Center, The Five Senses Institute, Rassoul Akram Hospital, Iran University of Medical Sciences, Tehran, Iran

ORCID:

Kaveh Abri Aghdam: https://orcid.org/0000-0001-7568-6455

Navid Manafi: https://orcid.org/0000-0002-4610-402X

\section{Abstract}

Purpose: To assess the use of temporal artery biopsy (TAB) in diagnosing giant cell arteritis (GCA) and to evaluate patients' clinical and laboratory characteristics.

Methods: We conducted a retrospective chart review of patients with suspected GCA who underwent TAB and had complete workup in a tertiary center in Iran between 2008 and 2017. The 2016 American College of Rheumatology (ACR) revised criteria for early diagnosis of GCA were used for each patient for inclusion in this study.

Results: The mean age of the 114 patients in this study was $65.54 \pm 10.17$ years. The mean overall score according to the 2016 ACR revised criteria was $4.17 \pm 1.39$, with 5.82 \pm 1.28 for positive biopsies and $3.88 \pm 1.19$ for negative biopsies $(p<0.001)$. Seventeen patients (14.9\%) had a positive biopsy. Although the mean post-fixation specimen length in the biopsy-positive group $(18.35 \pm 6.9 \mathrm{~mm})$ was longer than that in the biopsy-negative group $(15.62 \pm 8.4 \mathrm{~mm})$, the difference was not statistically significant $(P=0.21)$. There was no statistically significant difference between the groups in terms of sex, serum hemoglobin, platelet count, and erythrocyte sedimentation rate. There were statistically significant differences between the biopsy-negative and biopsy-positive groups with respect to patients' age and C-reactive protein level $(P<001$ and $P=0.012$, respectively). Conclusion: The majority of TABs were negative. Reducing the number of redundant biopsies is necessary to decrease workload and use of medical services. We suggest that the diagnosis of GCA should be dependent on clinical suspicion.

Keywords: Anterior Ischemic Optic Neuropathy; Giant Cell Arteritis; Temporal Arteritis; Temporal Artery Biopsy

J Ophthalmic Vis Res 2020; 15 (2): 201-209

\section{Correspondence to:}

Navid Manafi, MD. Department of Ophthalmology, Eye Research Center, The Five Senses Institute, Rassoul Akram hospital, Niayesh Ave., Sattarkhan St., Tehran 14456, Iran.

E-mail: drnavidmanafi@gmail.com

Received: 07-01-2019 Accepted: 23-11-2019

\section{Access this article online}

Website: https://knepublishing.com/index.php/JOVR

DOI: 10.18502/jovr.v15i2.6738

\section{INTRODUCTION}

Giant cell arteritis (GCA) is a systemic immunerelated vasculitis involving medium- and

This is an open access journal, and articles are distributed under the terms of the Creative Commons Attribution-NonCommercial-ShareAlike 4.0 License, which allows others to remix, tweak, and build upon the work non-commercially, as long as appropriate credit is given and the new creations are licensed under the identical terms.

How to cite this article: Abri Aghdam K, Soltan Sanjari M, Manafi N Khorramdel S, Alemzadeh SA, Ali Akbar Navahi R. Temporal Artery Biopsy for Diagnosing Giant Cell Arteritis: A Ten-year Review. J Ophthalmic Vis Res 2020;15:201-209. 
large-sized arteries, especially of the carotid branches, including the superficial temporal, ophthalmic, posterior ciliary, and occipital arteries. ${ }^{[1,2]}$ The inflammation of the arterial wall causes luminal obstruction and tissue ischemia. ${ }^{[3]}$ The involvement of these vessels can cause visual impairment or loss. Vision loss in GCA is usually due to arteritic anterior ischemic optic neuropathy, which is optic nerve head ischemia caused by inflammation of the wall of the posterior ciliary arteries. ${ }^{[1]}$

Correct diagnosis and urgent treatment with systemic corticosteroids are necessary to prevent major ischemic complications. ${ }^{[4]}$ Although there is no single test for diagnosing GCA, the American College of Rheumatology (ACR) 1990 GCA classification criteria can assist in the diagnosis of suspected cases. ${ }^{[5]}$ The presence of at least three of these five criteria carries a sensitivity of $93.5 \%$ and a specificity of $91.2 \%$ for GCA. ${ }^{[5,6]}$ In 2016 , a new and more extensive set of criteria for early diagnosis of the GCA was proposed. ${ }^{[7]}$ Table 1 shows the 2016 revised ACR ( $r A C R$ ) criteria for early diagnosis of GCA (previously called temporal arteritis). It has been suggested that in the presence of at least 3 out of 11 points, with at least one point belonging to domain I, a diagnosis of GCA can be made.

Temporal artery biopsy (TAB) is indicated for diagnosing suspected GCA cases. ${ }^{[8]}$ Although the value of TAB has been recently disputed because of its high false-negative rates, it remains the gold standard for diagnosis. ${ }^{[9]}$

The purpose of the current study was to investigate the use of TAB in diagnosing GCA at a tertiary center in Iran over a 10-year period. We investigated and discussed the clinical and laboratory results of patients with TAB-proven GCA and TABnegative cases according to the ACR criteria.

\section{METHODS}

We conducted a retrospective chart review in the Neuro-ophthalmology Clinic at the Rassoul Akram Hospital, a tertiary referral center in Tehran, Iran, between 2008 and 2017. The study was approved by the Ethics Committee of the Iran University of Medical Sciences and adhered to the tenets of the Declaration of Helsinki. We reviewed the medical records of patients with suspected GCA, including pathology reports of all TABs within this period. The 2016 rACR criteria for early diagnosis of giant cell (temporal) arteritis were considered for each patient for inclusion in this study. The agespecific maximal normal erythrocyte sedimentation rate (ESR) was calculated according to the following formulas: age in years $/ 2$ for men and (age in years $+10) / 2$ for women. ${ }^{[10]}$ Superficial TABs (STABs) were performed under local anesthesia using routine surgical techniques by either ophthalmology, vascular surgery, or neurosurgery residents with a wide spectrum of surgical expertise. ${ }^{[11]}$ The specimens were fixed in $10 \%$ formalin. The lengths of the formalin-fixed STAB samples on macroscopic examination were included in the reports. The specimens were processed using standard protocols for embedding tissue in paraffin wax blocks. The specimens were completely embedded, and histopathological sections were cut at three or more levels and examined after hematoxylin and eosin staining. All patients had undergone $T A B$ within 1-2 days after starting steroid treatment.

The checklist information for each patient included age, sex, laboratory test results (hemoglobin, platelet count, ESR, and C-reactive protein [CRP] levels), post-fixation STAB length, histological findings, side of biopsy, and notes of the ophthalmology team. Histological findings were documented with respect to the presence of multinucleated giant cells of Langerhans, inflammatory cell infiltration, intimal proliferation, and fragmentation of the internal elastic lamina. Details on the exact number of sections and levels examined were documented in most reports. Some of the cases were excluded for having an inappropriate biopsy specimen. All patients in the TAB-positive group had leukocyte infiltration (one point based on the rACR) and granuloma (one point based on the $\mathrm{rACR}$ ) in their histopathology specimens.

\section{Statistical Analysis}

SPSS software version 22.0 (IBM Corp., Armonk, NY) was used for statistical analyses. The Student's $t$-test was used for analyzing quantitative variables, and the Chi square test was used for qualitative variables. Results are reported as mean \pm standard deviation. $P$ values $<0.05$ were considered statistically significant. Statistical analysis was also performed to compare the first and second five years due to variation in specialties performing the biopsies and differences in the TAB specimen length over 10 years. 
Table 1. The 2016 revised ACR criteria for the diagnosis of $\mathrm{GCA}^{a}$

\begin{tabular}{|c|c|c|c|}
\hline Score & \multicolumn{3}{|c|}{ Entry } \\
\hline \multirow[t]{2}{*}{$\mathrm{N} / \mathrm{A}$} & & \multicolumn{2}{|c|}{ Age at onset $\geq 50$ years } \\
\hline & & \multicolumn{2}{|c|}{ Absence of exclusion criteria ${ }^{b}$} \\
\hline \multicolumn{4}{|l|}{ Domain I } \\
\hline 1 & & \multicolumn{2}{|c|}{ New-onset localized headache, ${ }^{c} 1$ point (p) } \\
\hline 1 & & \multicolumn{2}{|c|}{ Sudden onset of visual disturbance, ${ }^{c} 1$ point } \\
\hline 2 & & \multicolumn{2}{|c|}{ Polymyalgia rheumatica, 2 points } \\
\hline 1 & & \multicolumn{2}{|c|}{ Jaw claudication, ${ }^{c} 1$ point } \\
\hline 2 & & \multicolumn{2}{|c|}{ Abnormal temporal artery, ${ }^{d}$ up to 2 points } \\
\hline \multicolumn{4}{|l|}{ Domain II } \\
\hline 1 & & \multicolumn{2}{|c|}{ Unexplained fever and/or anemia, 1 point } \\
\hline 1 & & \multicolumn{2}{|c|}{$\mathrm{ESR} \geq 50 \mathrm{~mm} /$ hour, $^{e} 1$ point } \\
\hline 2 & & \multicolumn{2}{|c|}{ Compatible pathology, ${ }^{f}$ up to 2 points } \\
\hline \multicolumn{4}{|c|}{$\begin{array}{l}\text { ACR, American College of Rheumatology; ESR, erythrocyte sedimentation rate; GCA, giant cell arteritis; N/A, not applicable } \\
{ }^{a} \text { In the presence of three points or more out of the eleven with at least one point belonging to domain I along with all entry } \\
\text { criteria, a diagnosis of GCA can be established. } \\
{ }^{b} \text { The exclusion criteria included ear, nose, and throat or/and eye inflammation; kidney, skin, or peripheral nervous system } \\
\text { involvement; lung infiltration; lymphadenopathies; stiff neck; and digital gangrene or ulceration. } \\
{ }^{c} \text { No other etiologies can better explain any one of the criteria. } \\
{ }^{d} \text { Enlarged and/or pulseless temporal artery (one point)/tender temporal artery (one point). } \\
{ }^{e} \text { It must be ignored in the presence of polymyalgia rheumatica. } \\
{ }^{f} \text { Vascular and/or perivascular fibrinoid necrosis along with leucocyte infiltration (one point) and granuloma (one point). }\end{array}$} \\
\hline \multicolumn{4}{|c|}{ Table 2. Comparison between TAB-negative and TAB-positive patients according to the 2016 revised ACR criteria } \\
\hline & TAB-positive $(n=17)$ & TAB-negative $(\mathrm{n}=97)$ & P-value \\
\hline ESR (mm/hour) & $52.50 \pm 33.28$ & $52.30 \pm 28.21$ & 0.98 \\
\hline Hemoglobin (g/dl) & $12.40 \pm 1.95$ & $11.97 \pm 1.80$ & 0.38 \\
\hline Age (years) & $75.66 \pm 8.32$ & $63.92 \pm 9.51$ & $<0.001$ \\
\hline Temporal tenderness & $29.41 \%$ & $35.05 \%$ & 0.61 \\
\hline Jaw claudication & $41.2 \%$ & $26.8 \%$ & 0.45 \\
\hline Pulseless temporal artery & $17.64 \%$ & $10.30 \%$ & 0.26 \\
\hline
\end{tabular}

ACR, American College of Rheumatology; ESR, erythrocyte sedimentation rate; TAB, temporal artery biopsy

\section{RESULTS}

In the primary collection of patient records, 257 patient charts were reviewed and analyzed. The patients who lacked the 2016 rACR criteria, an appropriate biopsy report, or the associated blood test results were excluded. After also excluding patients with incomplete medical records, 114 patients with complete required information in their charts who met the 2016 rACR criteria were evaluated. Of these, 43 patients (37.7\%) were male and $71(62.3 \%)$ were female, with an overall mean age of $65.54 \pm 10.17$ years at the time of biopsy. Of the 114 biopsies included in the study, 17 (14.9\%) showed the characteristics of GCA. The mean age of TAB-negative patients [Figure 1] was $63.92 \pm 9.51$ years compared to a mean age of $75.66 \pm 8.32$ years in TAB-positive cases [Figure 2] $(P<0.001)$. In patients with positive biopsies, the mean CRP level was $30.50 \pm 32.35 \mathrm{mg} / \mathrm{L}$, whereas in those with negative biopsies, it was $13.68 \pm 18.91 \mathrm{mg} / \mathrm{L}(P$ $=0.009$ ). An abnormal ESR and ESR $>50 \mathrm{~mm} / \mathrm{hour}$ were present in $61 \%$ and $44 \%$ of cases, respectively. The mean overall score according to the 2016 ACR 
Table 3. Comparison of the first and second five years in terms of biopsy result and length

\begin{tabular}{|c|c|c|c|c|c|c|}
\hline \multirow[t]{2}{*}{ Biopsy year } & \multirow[t]{2}{*}{ Number of biopsies } & \multicolumn{2}{|c|}{ Biopsy result } & \multirow[t]{2}{*}{ P-value } & \multirow[t]{2}{*}{ Biopsy length (mm) } & \multirow[t]{2}{*}{ P-value } \\
\hline & & Negative & Positive & & & \\
\hline First five years & 59 & 53 & 6 & 0.06 & $14.94 \pm 9.25$ & 0.03 \\
\hline Second five years & 47 & 36 & 11 & & $17.42 \pm 6.88$ & \\
\hline
\end{tabular}

revised criteria was $4.17 \pm 1.39$, with $5.82 \pm 1.28$ for positive biopsies and $3.88 \pm 1.19$ for negative biopsies $(p<0.001)$.

Although the mean post-fixation specimen length in the biopsy-positive group (18.35 \pm $6.9 \mathrm{~mm})$ was longer than that in the biopsynegative group $(15.62 \pm 8.4 \mathrm{~mm})$, the difference was not statistically significant $(P=0.21)$. Of the 114 patients, 96 cases presented with acute visual loss; $83(86.4 \%)$ of them had anterior ischemic optic neuropathy (69 subjects in the TAB-negative group and 14 in the TAB-positive group); 8 (8.3\%) were diagnosed with posterior ischemic optic neuropathy (seven cases in the TAB-negative group and one in the TAB-positive group); and 5 (5.2\%) cases had central retinal artery occlusion (four cases in the TAB-negative group and one in the TAB-positive group). Three other patients developed acute cranial nerve palsies; two patients had sudden third nerve palsy, and one case presented with acute sixth nerve palsy.

Table 2 compares the TAB-positive and TABnegative groups in terms of 2016 rACR scoring. Except for age, there was no significant difference between the biopsy-positive and biopsy-negative groups in terms of their symptoms (all $P$-values $>$ 0.05).

We also compared the results of first and second five years to evaluate the human factor effect during this time period [Table 3]. We observed a significant increase in the specimen length obtained during the second five years $(P=0.03)$ but nonsignificant rise in the number of positive biopsies (odds ratio $=2.69, P=0.06$ ).

\section{DISCUSSION}

This study describes the results of a cohort of 114 patients who met the 2016 rACR criteria for the diagnosis of GCA and underwent TAB over a 10year period in a tertiary center in Tehran, Iran. We aimed to evaluate the results of biopsies as well as clinical and laboratory features of suspected GCA.

Although the overall mean age at biopsy in our patients was 65.5 years, we observed a significantly higher mean age in TAB-positive patients than that in TAB-negative ones (75.6 compared to 63.9 years). This finding reflects the increase in GCA incidence with age.

There is controversy regarding the impact of the length of biopsy on the results of TAB. Table 4 summarizes the characteristics of previously published studies about the association between TAB length and its diagnostic yield. Due to the probability of the presence of skip lesions, particularly in cases with insufficient specimen size, falsenegative results (15-29\%) may occur. ${ }^{[12]}$ Ashton-Key and Gallagher found $10-61 \%$ false negativity and $6 \%$ false positivity in TABs due to arteriosclerosis as a result of aging and not the inflammatory process. $^{[13]}$

The ESR and CRP levels are biochemical markers that increase in GCA. We found a nonsignificant difference in the mean ESR between cases with a positive and those with a negative biopsy, but there was a statistically significant higher CRP level in the group of patients with a positive $T A B$ than in the group with a negative TAB. However, no score has been considered for CRP according to the 2016 rACR criteria for the diagnosis of GCA.

The 1990 ACR diagnostic criteria for GCA consists of age at disease onset of 50 years or older, new headache, temporal artery abnormality, elevated ESR, and abnormal TAB. Omitting the biopsy item from the 1990 ACR score leaves only four criteria, which makes it difficult to justify not performing $T A B$ for low- or high-risk patients. The applicability of the 1990 ACR criteria for the diagnosis of GCA according to its symptoms is another challenging issue. Murchison et al challenged the 1990 ACR criteria for the diagnosis of GCA. ${ }^{[14]}$ They found that nearly $25 \%$ of the patients with positive TABs 
Table 4. Previous studies on the length of superficial temporal artery biopsy (STAB)

\begin{tabular}{|c|c|c|c|c|c|c|c|c|}
\hline Study & Year & Location & Study design & $\begin{array}{c}\text { Number of } \\
\text { cases }\end{array}$ & $\begin{array}{l}\text { Number of } \\
\text { biopsies }\end{array}$ & $\begin{array}{c}\text { Mean } \\
\text { biopsy } \\
\text { length }(\mathrm{mm})\end{array}$ & $\begin{array}{l}\text { Positivity } \\
\text { rate }(\%)^{a}\end{array}$ & $\begin{array}{l}\text { Main finding and } \\
\text { conclusion }\end{array}$ \\
\hline $\begin{array}{l}\text { Allison } \\
\text { et al }{ }^{[23]}\end{array}$ & 1984 & UK & $\begin{array}{l}\text { Retrospective } \\
\text { review }\end{array}$ & 132 & 132 & 7.9 & 64 & $\begin{array}{l}\text { Size of } 7 \mathrm{~mm} \text { is } \\
\text { recommended for more } \\
\text { accurate results }\end{array}$ \\
\hline Kent et $\mathrm{al}^{[24]}$ & 1990 & USA & $\begin{array}{l}\text { Retrospective } \\
\text { review }\end{array}$ & 70 & 73 & $\mathrm{~N} / \mathrm{S}$ & 11.4 & $\begin{array}{l}\text { Generous biopsy of } \sim 5 \mathrm{~cm} \\
\text { of fresh vessel } \\
\text { recommended to confirm } \\
\text { a suspected diagnosis of } \\
\text { temporal arteritis }\end{array}$ \\
\hline $\begin{array}{l}\text { Achkar } \\
\text { et al }{ }^{[25]}\end{array}$ & 1994 & USA & $\begin{array}{l}\text { Consecutive } \\
\text { case series }\end{array}$ & 535 & 535 & 36.32 & 33 & $\begin{array}{l}\text { Suggested to obtain } \\
\text { samples } \geq 20 \mathrm{~mm}\end{array}$ \\
\hline $\begin{array}{l}\text { Sudlow } \\
\text { et al }{ }^{[26]}\end{array}$ & 1997 & Scotland & $\begin{array}{l}\text { Retrospective } \\
\text { review }\end{array}$ & $\mathrm{N} / \mathrm{S}$ & 200 & 9.14 & 27.02 & $\begin{array}{l}\text { Longer specimens may be } \\
\text { more likely to yield a } \\
\text { positive result }\end{array}$ \\
\hline $\begin{array}{l}\text { Taylor- } \\
\text { Gjevre } \\
\text { et al }{ }^{[27]}\end{array}$ & 2005 & Canada & $\begin{array}{l}\text { Retrospective } \\
\text { review }\end{array}$ & 141 & 141 & 17.6 & 27 & $\begin{array}{l}\text { More positive results at } \\
\text { post-fixation length of } 10 \\
\mathrm{~mm}\end{array}$ \\
\hline $\begin{array}{l}\text { Arashvand } \\
\text { et al }{ }^{[28]}\end{array}$ & 2006 & UK & $\begin{array}{l}\text { Retrospective } \\
\text { review }\end{array}$ & $\mathrm{N} / \mathrm{S}$ & 117 & $11.95 \pm 7.91$ & 26 & $\begin{array}{l}\text { Raising or lowering the } \\
\text { minimum threshold length } \\
\text { did not yield a statistically } \\
\text { significant difference in } \\
\text { the rate of positive results }\end{array}$ \\
\hline Mahr et al ${ }^{[29]}$ & 2006 & France & $\begin{array}{l}\text { Retrospective } \\
\text { review }\end{array}$ & 1520 & 1520 & $13.3 \pm 7.2$ & 14.7 & $\begin{array}{l}\text { Biopsy sample size of } 5 \\
\mathrm{~mm} \text { is adequate }\end{array}$ \\
\hline $\begin{array}{l}\text { Sharma } \\
\text { et al }{ }^{[29]}\end{array}$ & 2007 & Australia & $\begin{array}{l}\text { Retrospective } \\
\text { observational } \\
\text { study }\end{array}$ & 157 & 157 & 11.85 & $\mathrm{~N} / \mathrm{S}$ & $\begin{array}{l}\text { Specimens of } \geq 20 \mathrm{~mm} \\
\text { were } 2.8 \text { times more likely } \\
\text { to show features of GCA } \\
\text { than those }<20 \mathrm{~mm}\end{array}$ \\
\hline $\begin{array}{l}\text { Breuer } \\
\text { et al }{ }^{[31]}\end{array}$ & 2009 & Israel & $\begin{array}{l}\text { Retrospective } \\
\text { review }\end{array}$ & 173 & 305 & 11.9 & 35.4 & $\begin{array}{l}\text { Longer samples are more } \\
\text { accurate }\end{array}$ \\
\hline $\begin{array}{l}\text { Ypsilantis } \\
\text { et al }{ }^{[32]}\end{array}$ & 2011 & UK & Cohort & 966 & 966 & 10 & 21.4 & $\begin{array}{l}\text { A } 10-\mathrm{mm} \text { sample is } \\
\text { satisfactory (post-fixation } \\
\text { length of } \geq 7 \mathrm{~mm} \text { ) }\end{array}$ \\
\hline $\begin{array}{l}\text { Kaptanis } \\
\text { et al }{ }^{[33]}\end{array}$ & 2014 & UK & $\begin{array}{l}\text { Retrospective } \\
\text { review }\end{array}$ & 149 & 151 & $6.4 \pm 3$ & 13.3 & $\begin{array}{l}\text { No relation between } \\
\text { length and results; hence } \\
\text { post-fixation length of } 6 \\
\mathrm{~mm} \text { is satisfactory (biopsy } \\
\text { length }>10 \mathrm{~mm} \text { ) }\end{array}$ \\
\hline Au et $\mathrm{al}^{[4]}$ & 2016 & Australia & $\begin{array}{l}\text { Retrospective } \\
\text { observational }\end{array}$ & 96 & 96 & $16 \pm 7.3$ & 20.8 & $\begin{array}{l}\text { Length of biopsy is not an } \\
\text { independent factor in } \\
\text { positivity rate }\end{array}$ \\
\hline $\begin{array}{l}\text { Grossman } \\
\text { et } \mathrm{al}^{[34]}\end{array}$ & 2016 & Israel & $\begin{array}{l}\text { Retrospective } \\
\text { analysis }\end{array}$ & 240 & 240 & $10.7 \pm 5.7$ & 25.83 & $\begin{array}{l}\text { Length of biopsy is not a } \\
\text { determining factor }\end{array}$ \\
\hline $\begin{array}{l}\text { Gajree } \\
\text { et al }{ }^{[35]}\end{array}$ & 2017 & Scotland & $\begin{array}{l}\text { Retrospective } \\
\text { analysis }\end{array}$ & 715 & 715 & $11.64 \pm 6.4$ & 35 & $\begin{array}{l}\text { Length of specimen does } \\
\text { not necessarily change } \\
\text { the likelihood of a positive } \\
\text { biopsy }\end{array}$ \\
\hline $\begin{array}{l}\text { Papadakis } \\
\text { et al }{ }^{[36]}\end{array}$ & 2017 & Germany & $\begin{array}{l}\text { Retrospective } \\
\text { analysis }\end{array}$ & 116 & 116 & 9.4 & 55.2 & $\begin{array}{l}\text { TAB length is not } \\
\text { associated with the TAB } \\
\text { diagnostic yield in patients } \\
\text { with clinical suspicion of } \\
\text { GCA }\end{array}$ \\
\hline
\end{tabular}


Table 4. Continued.

\begin{tabular}{|c|c|c|c|c|c|c|c|c|}
\hline Study & Year & Location & Study design & $\begin{array}{c}\text { Number of } \\
\text { cases }\end{array}$ & $\begin{array}{c}\text { Number of } \\
\text { biopsies }\end{array}$ & $\begin{array}{l}\text { Mean biopsy } \\
\text { length }(\mathrm{mm})\end{array}$ & $\begin{array}{l}\text { Positivity } \\
\text { rate (\%) }{ }^{a}\end{array}$ & $\begin{array}{l}\text { Main finding and } \\
\text { conclusion }\end{array}$ \\
\hline Oh et al ${ }^{[12]}$ & 2018 & Australia & $\begin{array}{l}\text { Retrospective } \\
\text { case-control } \\
\text { of } \\
\text { consecutive } \\
\text { cohort }\end{array}$ & 538 & 538 & $17.6 \pm 9.1$ & 23.4 & $\begin{array}{l}\text { Biopsy length of } \geq \\
15 \mathrm{~mm} \text { is } \\
\text { suggested }\end{array}$ \\
\hline Current study & 2019 & Iran & $\begin{array}{l}\text { Retrospective } \\
\text { analysis }\end{array}$ & 114 & 114 & $16.05 \pm 8.27$ & 14.9 & $\begin{array}{l}\text { TAB length is not } \\
\text { significantly } \\
\text { different in } \\
\text { positive and } \\
\text { negative biopsies; } \\
\text { also, the majority } \\
\text { of TABs are } \\
\text { negative }\end{array}$ \\
\hline
\end{tabular}

GCA, giant cell arteritis; N/S, not stated; TAB, temporal artery biopsy

${ }^{a}$ Rate of positive biopsies in all biopsies

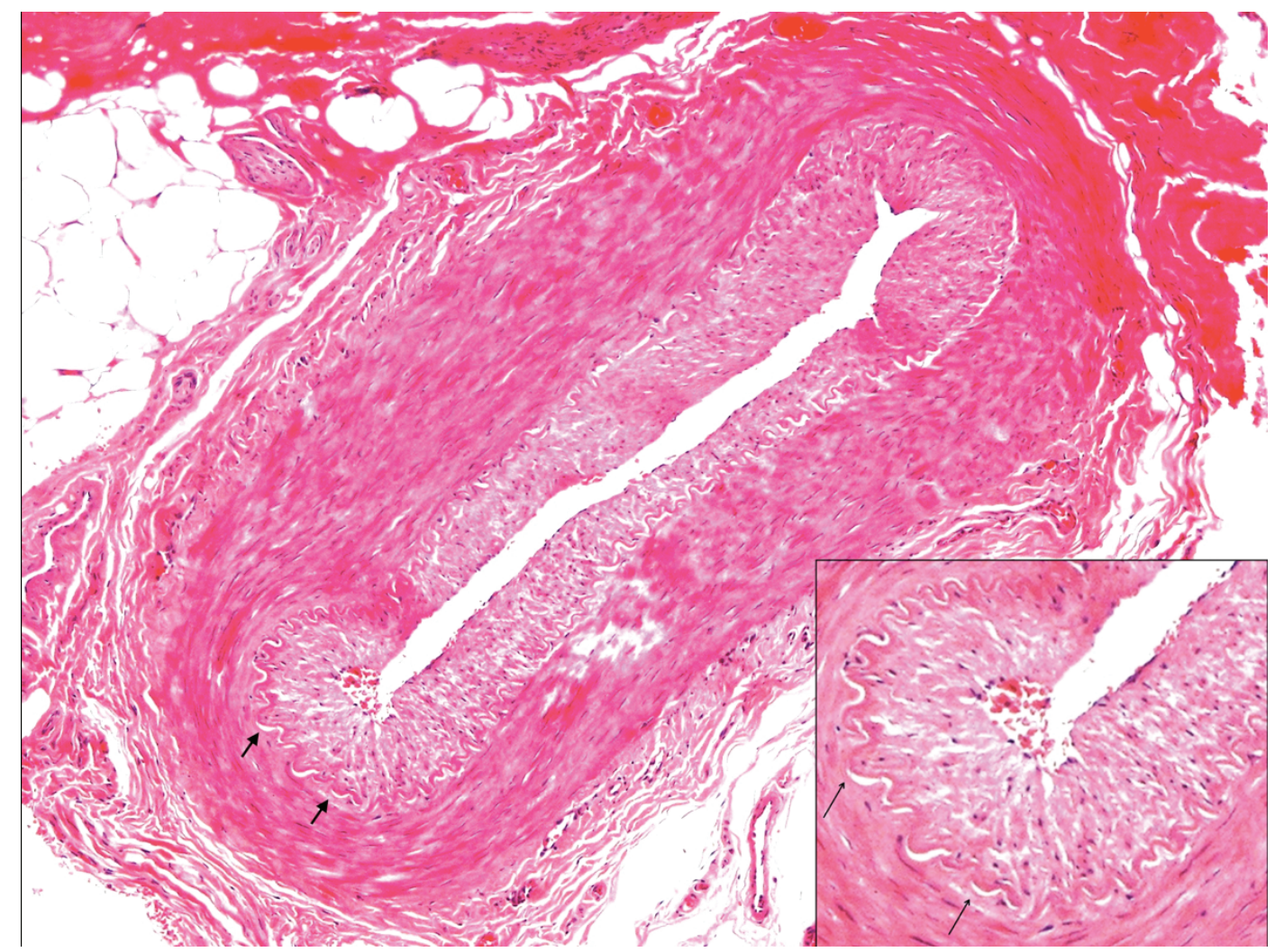

Figure 1. Histopathology section of a negative temporal artery biopsy. Note the intact lamina elasticum (short arrows) and the absence of inflammation (hematoxylin and eosin staining, 100x magnification).

did not fulfill the ACR criteria (probably because $20 \%$ of the GCA patients have occult GCA). In contrast, $28.3 \%$ of the patients met the criteria but were biopsy negative. Ing et al developed a new prediction model for diagnosing patients with suspected GCA. ${ }^{[15]}$ Their results are similar to ours in terms of more positive biopsy results in the elderly population as well as more jaw claudication, more ischemic optic neuropathy, and higher platelet levels, ESR, and CRP levels 


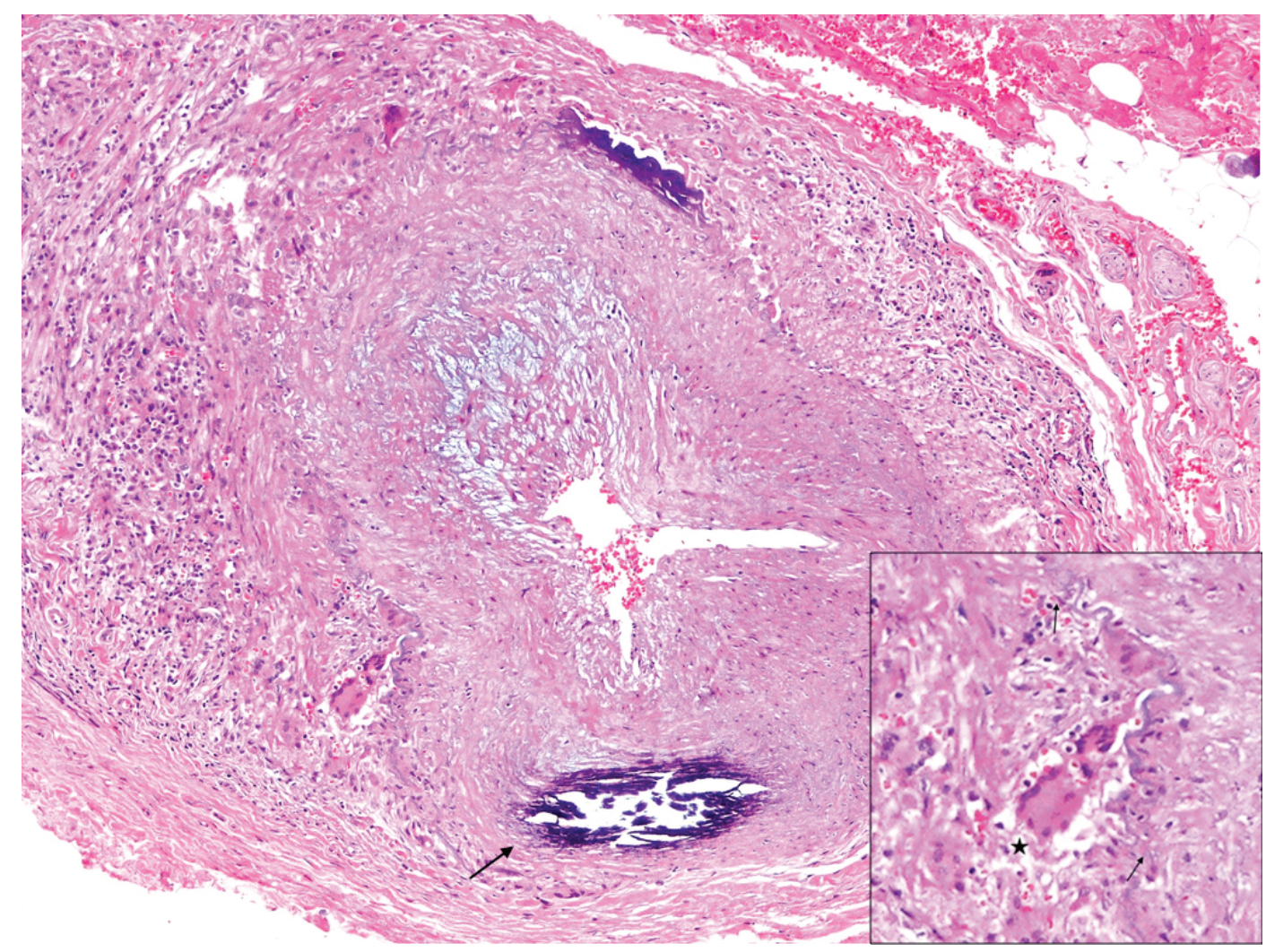

Figure 2. GCA-positive temporal artery biopsy (H\&E staining, 100× magnification). Note the narrowing of the arterial lumen and infiltration of inflammatory cells and multinucleated giant cells (asterisk) in addition to the destruction of the lamina elasticum (short arrows). Age-related intramural calcification is also noted in this specimen (long arrow). GCA, giant cell arteritis; H\&E, hematoxylin and eosin.

in the positive biopsy group than in the negative biopsy group. They found these variables significant predictors of positive TAB results. However, the 2016 rACR criteria has nine non-biopsy items, which could permit greater differentiation of patients with respect to the likelihood of a positive TAB result and GCA diagnosis. Based on the 2016 rACR criteria for the diagnosis of GCA, Sait et al proposed a simple management plan: (1) 2016 rACR scores $\leq 2$ may not mandate a biopsy as these patients are very unlikely to have GCA; (2) patients with scores $\geq 5$ will also not need TAB as they are likely to have GCA and should continue steroid therapy; and (3) a biopsy will be required in cases with scores of 3 and 4 because these patients have the most variability in TAB results. ${ }^{[16]}$ However, further studies involving multiple centers with firm inclusion criteria should be performed before an algorithm that avoids biopsy in GCA management is applied.

In our study, TAB-positive patients had a higher mean overall rACR score than the TAB-negative patients. One reason could be that TAB-positive patients with compatible pathology accumulate two more points in comparison with TAB-negative patients. Sait et al compared the functional utility of $r A C R$ criteria against the original ACR criteria and found that the more extensive $\mathrm{rACR}$ can serve as a more useful guide to reduce the number of unnecessary biopsies. ${ }^{[16]}$

In case of TAB-positive results in the first and second five years, the odds ratio was approximately 2.7 (comparing second five years to the first five years), even though the $P$-value was borderline. The increase in the specimen length can be due to human factors. TABs were performed by several different specialties in our center. Some TABs were carried out by neurosurgery and vascular surgery residents in the first five-year interval, but the Department of Ophthalmology was exclusively in charge of performing biopsies in the second five-year interval. The ophthalmology team was more experienced in the second five years than in the first; however, our results indicated that specimen length beyond a certain size did 
not influence the rate of positive results. The proficiency of the pathology team may also play an important role in analyzing specimens.

In recent years, other diagnostic modalities have gained popularity because of their high specificity, sensitivity, and ease of use. Color Doppler Ultrasound (CDUS) has been shown to have a specificity of $78-100 \%$ and a sensitivity of $55-100 \%$ for diagnosing GCA ${ }^{[17]}$ Although extensive experience is needed for a proper diagnosis with CDUS, its high resolution of $0.1 \mathrm{~mm}$ and its noninvasiveness makes it a good choice as a diagnostic tool. With CDUS, not only the temporal artery can be visualized, but also other cranial arteries as well as axillary and subclavian arteries can be visualized for signs of vasculitis. ${ }^{[18-20]}$ High-resolution magnetic resonance imaging with magnetic resonance angiography (MRA) has been reported to have a pooled sensitivity of $73 \%$ and a specificity of $88 \%$. This modality can show the temporal arteries and demonstrate mural edema if contrast is administered. ${ }^{[21]}$ Other modalities, including positron emission tomography (PET), computed tomography (CT), CT with angiography, and conventional MRA, lack sufficient spatial resolution to permit visualization of the temporal artery and hence are not the preferred modalities in GCA. Due to high fluorodeoxyglucose uptake in the brain, PET scanning of cranial arteries is considerably obscured. ${ }^{[22]}$

This study has several limitations. Because of its retrospective nature, we encountered a considerable amount of missing data that yielded a lower sample size than we originally anticipated. This might result in selection bias. Moreover, these results do not illustrate the whole population, as we included only patients from a tertiary referral center. Despite these limitations, this is the first study performed in Iran to evaluate the results of $\mathrm{TAB}$ and the clinical and laboratory characteristics of patients with suspected GCA.

In conclusion, we could not find an association between the analysis of TABs and the clinical evaluation of patients with GCA. Although TAB is still considered the gold standard test for GCA diagnosis, clinicians should consider both clinical and pathological data to manage difficult cases. This study shows that the majority of TABs are negative, and reducing the number of redundant biopsies is necessary to lower the workload of medical staff and the use of medical services.

\section{REFERENCES}

1. Chew SS, Kerr NM, Danesh-Meyer H V. Giant cell arteritis. J Clin Neurosci 2009;16:1263-1268.

2. Hayreh SS. Ischemic optic neuropathy. Prog Retin Eye Res 2009;28:34-62.

3. Hayreh SS. Ischemic optic neuropathies - where are we now? Graefes Arch Clin Exp Ophthalmol 2013;251:18731884.

4. Au CP, Sharma NS, McCluskey P, Ghabrial R. Increase in the length of superficial temporal artery biopsy over 14 years. Clin Exp Ophthalmol 2016;44:550-554.

5. Hunder GG, Bloch DA, Michel BA, Stevens MB, Arend WP, Calabrese LH, et al. The American College of Rheumatology 1990 criteria for the classification of giant cell arteritis. Arthritis Rheum 1990;33:1122-1128.

6. Tehrani R, Ostrowski RA, Hariman R, Jay WM. Giant cell arteritis. Semin Ophthalmol 2008;23:99-110.

7. Salehi-Abari I. 2016 ACR revised criteria for early diagnosis of giant cell (temporal) arteritis. Autoimmune Dis Ther Approaches Open Access 2016;3:1-4.

8. Cristaudo AT, Mizumoto R, Hendahewa R. The impact of temporal artery biopsy on surgical practice. Ann Med Surg 2016;11:47-51.

9. Manjuka R, David TAH. Temporal artery biopsies: a fresh perspective. ANZ J Surg 2010;80:479-80.

10. Miller A, Green M, Robinson D. Simple rule for calculating normal erythrocyte sedimentation rate. Br Med J (Clin Res Ed) $1983 ; 286: 266$.

11. Cahais J, Houdart R, Lupinacci RM, Valverde A. Operative technique: superficial temporal artery biopsy. J Visc Surg 2017;154:203-207.

12. Oh LJ, Wong E, Gill AJ, McCluskey P, Smith JEH. Value of temporal artery biopsy length in diagnosing giant cell arteritis. ANZ J Surg 2018;88:191-195.

13. Ashton-Key MR, Gallagher PJ. False-negative temporal artery biopsy. Am J Surg Pathol 1992;16:634-635.

14. Murchison AP, Gilbert ME, Bilyk JR, Eagle Jr. RC, Pueyo $\mathrm{V}$, Sergott RC, et al. Validity of the American College of Rheumatology criteria for the diagnosis of giant cell arteritis. Am J Ophthalmol 2012;154:722-729.

15. Ing EB, Lahaie Luna G, Toren A, Ing R, Chen JJ, Arora N, et al. Multivariable prediction model for suspected giant cell arteritis: development and validation. Clin Ophthalmol 2017;11:2031-2042.

16. Sait MR, Lepore M, Kwasnicki R, Allington J, Balasubramanian R, Somasundaram SK, et al. The 2016 revised ACR criteria for diagnosis of giant cell arteritis - our case series: can this avoid unnecessary temporal artery biopsies? Int J Surg Open 2017;9:19-23.

17. Buttgereit F, Dejaco C, Matteson EL, Dasgupta B. Polymyalgia rheumatica and giant cell arteritis a systematic review. JAMA 2016;315:2442-2458.

18. Pfadenhauer K, Esser M, Berger K. Vertebrobasilar ischemia and structural abnormalities of the verte- 
bral arteries in active temporal arteritis and polymyalgia rheumatica - an ultrasonographic case-control study. $J$ Rheumatol 2005;32:2356-2360.

19. Schmidt WA, Seifert A, Gromnica-ihle E, Krause A, Natusch A. Ultrasound of proximal upper extremity arteries to increase the diagnostic yield in large-vessel giant cell arteritis. Rheumatology 2008;47:96-101.

20. Czihal M, Zanker S, Rademacher A, Tatò F, Kuhlencordt PJ, Schulze-Koops $\mathrm{H}$, et al. Sonographic and clinical pattern of extracranial and cranial giant cell arteritis. Scand $J$ Rheumatol 2012;41:231-236.

21. Bley TA, Wieben $O$, Uhl M, Thiel J, Schmidt D, Langer M. High-resolution MRI in giant cell arteritis: imaging of the wall of the superficial temporal artery. Am J Roentgenol 2005;184:283-287.

22. Docken WP. Diagnosis of giant cell arteritis. In: UpToDate. UpToDate Inc.; 2019.

23. Allison MC, Gallagher PJ. Temporal artery biopsy and corticosteroid treatment. Ann Rheum Dis 1984;43:416-417.

24. Kent 3rd RB, Thomas L. Temporal artery biopsy. Am Surg 1990;56:16-21.

25. Achkar AA, Lie JT, Hunder GG, O'Fallon WM, Gabriel $\mathrm{SE}$. How does previous corticosteroid treatment affect the biopsy findings in giant cell (temporal) arteritis? Ann Intern Med 1994;120:987-992.

26. Sudlow C. Diagnosing and managing polymyalgia rheumatica and temporal arteritis. Sensitivity of temporal artery biopsy varies with biopsy length and sectioning strategy. BMJ 1997;315:549.

27. Taylor-Gjevre R, Vo M, Shukla D, Resch L. Temporal artery biopsy for giant cell arteritis. J Rheumatol 2005;32:12791282.
28. Arashvand $\mathrm{K}$. The value of temporal artery biopsy specimen length in the diagnosis of giant cell arteritis. $J$ Rheumatol 2006;33:2363-2364; author reply 2364.

29. Mahr A, Saba M, Kambouchner M, Polivka M, Baudrimont $\mathrm{M}$, Brocheriou I, et al. Temporal artery biopsy for diagnosing giant cell arteritis: the longer, the better? Ann Rheum Dis 2006;65:826-828.

30. Sharma NS, Ooi JL, McGarity BH, Vollmer-Conna U, McCluskey P. The length of superficial temporal artery biopsies. ANZ J Surg 2007;77:437-439.

31. Breuer GS, Nesher R, Nesher G. Effect of biopsy length on the rate of positive temporal artery biopsies. Clin Exp Rheumatol 2009;27:S10-S13.

32. Ypsilantis E, Courtney ED, Chopra N, Karthikesalingam A, Eltayab M, Katsoulas $\mathrm{N}$, et al. Importance of specimen length during temporal artery biopsy. $\mathrm{Br} J$ Surg 2011;98:1556-1560.

33. Kaptanis S, Perera JK, Halkias C, Caton N, Alarcon L, Vig S. Temporal artery biopsy size does not matter. Vascular 2014;22:406-410.

34. Grossman C, Barshack I, Bornstein G. Association between specimen length and diagnostic yield of temporal artery biopsy. Scand J Rheumatol 2016;9742:26.

35. Gajree S, Borooah S, Dhillon N, Goudie C, Smith C, Aspinall P, et al. Temporal artery biopsies in south-east Scotland: a five year review. $J R$ Coll Physicians Edinb 2017;47:124-128.

36. Papadakis M, Kaptanis S, Kokkori-Steinbrecher A, Floros N, Schuster F, Hubner G. Temporal artery biopsy in the diagnosis of giant cell arteritis: bigger is not always better. Am J Surg 2018;215:647-650. 